\title{
REVISTAMARACANAN
}

Dossiê

\section{"Acima da América está o sangue": a eugenia nos escritos de Monteiro Lobato}

\author{
"Blood is above America" " eugenics in the writings of Monteiro Lobato
}

\author{
Arlindo Ferretti Junior* \\ Universidade da Região de Joinville \\ Joinville, Santa Catarina, Brasil \\ Euler Renato Westphal** \\ Universidade da Região de Joinville \\ Joinville, Santa Catarina, Brasil

\section{Roberta Barros Meira***} \\ Universidade da Região de Joinville \\ Joinville, Santa Catarina, Brasil
}

Recebido em: 01 set. 2020.

Aprovado em: 27 nov. 2020.

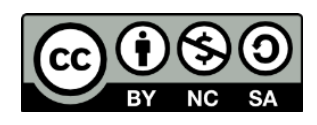

O presente trabalho foi realizado com apoio da Coordenação de Aperfeiçoamento de Pessoal de Nível Superior (Capes), Código de Financiamento 001.

* Mestre em Patrimônio Cultural e Sociedade e licenciado em História pela Universidade da Região de Joinville (UNIVILLE) e pesquisador do grupo de pesquisa em "Imaterialidade da cultura material em uma perspectiva interdisciplinar: Patrimônio Cultural, Teologia e Sociedade". (jnferretti@gmail.com)
(iD) https://orcid.org/0000-0001-9051-2592
(9) http://lattes.cnpq.br/0238291460660625

** Professor titular da Universidade da Região de Joinville e professor da Faculdade Luterana de Teologia, São Bento do Sul-SC. Doutor em Teologia pela Faculdade EST. (eulerwestphal@gmail.com)

(iD) https://orcid.org/0000-0002-4891-8692

*** Professora do Programa de Pós-graduação em Patrimônio Cultural e Sociedade da Universidade da Região de Joinville (UNIVILLE). Doutora e mestre em História Econômica pela Universidade de São Paulo. (rbmeira@gmail.com)

(1) https://orcid.org/0000-0001-7739-216X

(9) http://lattes.cnpq.br/5410201062168341 


\title{
Resumo
}

Este artigo procura discutir algumas das passagens dispostas nos escritos de Monteiro Lobato que dialogam com posturas eugenistas. Para tanto, observamos mais de perto dois de seus textos: "O presidente negro" (1926) e "América" (1932), que servirão de base para analisar seus escritos da juventude à velhice. Veem-se reflexos dessas posições em cartas trocadas com Renato Kehl e Artur Neiva. As análises indicam a presença de concepções eugenistas ora associadas a uma perspectiva mais radical, ora mais próximas a algumas vertentes das práticas sanitaristas, à época em voga no Brasil. Em sua busca por levar o país ao progresso, o autor articulou perspectivas cientificistas comuns em seu tempo. É nesse sentido que procuramos fazer uma reflexão crítica sobre a circulação de ideias eugenistas e o seu impacto na construção do projeto de identidade nacional lobatiano.

Palavras-chave: Ciência. Identidade. Eugenia. Monteiro Lobato.

\begin{abstract}
This article seeks to discuss some of the passages in the writings of Monteiro Lobato that dialogue with eugenicist postures. To do so, we take a closer look at two of his texts: "The Black President" (1926) and "America" (1932), which will serve as platforms for a look at his writings from youth to old age. We see reflections of these positions in letters exchanged with Renato Kehl and Artur Neiva. The analyses indicate the presence of eugenicist conceptions sometimes associated with a more radical perspective, sometimes closer to sanitary practices, at the time in vogue in Brazil. In his search to lead the country to progress, the author has articulated common scientific perspectives in his time. It is in this sense that we seek to make a critical reflection on the circulation of eugenicist ideas and the construction of the Lobatian national identity project.
\end{abstract}

Keywords: Science. Identity. Eugenics. Monteiro Lobato. 


\section{Introdução}

Monteiro Lobato nasceu em 18 de abril de 1882 e morreu em 4 de julho de 1948. Nacionalmente conhecido por seus livros infantis, sobretudo os da série "Sítio do Pica-Pau Amarelo". ${ }^{1}$ O autor também teve papel notável como publicista, além de ter escrito textos direcionados ao público adulto, como contos e artigos. Ele se relacionou com movimentos políticos e intelectuais de seu tempo e atuou na propagação dos ideais de progresso, que no Brasil estavam principalmente associados às reformas sanitárias e educacionais, e à modernização produtiva, tanto no setor agrícola quanto na indústria².

O clima cientificista ${ }^{3}$ de seus dias foi materializado em seus textos. Lobato (1964c) admite influências de uma vasta gama de autores, mencionando nomes como os do pensador evolucionista inglês Herbert Spencer (1820-1903) e dos cientistas franceses Augusto Comte (1798-1857) e Gustave Le Bon (1841-1931). Os textos deste último, escreve Lobato (1964c, p. 221), são um tratado de "desasnamento". Ainda, é possível perceber que o autor dedica numerosas linhas ao filósofo alemão Friedrich Nietzsche (1844-1900). Todos esses homens estavam envolvidos, de alguma forma, com a alçada da perspectiva biológica sobre todas as áreas do conhecimento.

Como sustentado por de Souza et al., ${ }^{4}$ a temática científica é recorrente na literatura brasileira da virada do século XIX para o XX. Pode-se observar desde incorporações profundas do zeitgeist médico hegemônico, a exemplo do que fez o poeta Augusto dos Anjos, até críticas contundentes direcionadas ao dogmatismo científico, vistas nas produções de Machado de Assis

\footnotetext{
${ }^{1}$ Lembramos que as ideias raciais defendidas por Lobato também estão presentes em suas obras infantis (cf. HABIB, Paula Arantes Botelho Briglia. Eis o mundo encantado que Monteiro Lobato criou: raça, eugenia e nação. 2003. Dissertação (mestrado) - Universidade Estadual de Campinas, Instituto de Filosofia e Ciencias Humanas, Campinas, SP.). O tema foi amplamente discutido, tanto em ambiente acadêmico, quanto nos espaços midiáticos. O racismo presente nos livros infantis do autor gera debates acalorados e tentativas de restrição de sua distribuição (Cf. MENDES, Priscilla. Mais uma obra de Monteiro Lobato é questionada por suposto racismo. G1, Brasília, 25 set. 2012. Educação. Acesso em: 11 jan. 2021.).
}

${ }^{2}$ CAVALHEIRO, Edgard. Monteiro Lobato: vida e obra. 3. ed. São Paulo: Brasiliense. 1962. 2 v.

3 O cientificismo é um movimento que se caracteriza por transformar em dogmas os princípios científicos, reivindicando serem estes capazes de explicar todos os fenômenos da realidade (Cf. TODOROV, Tzvetan. Imperfect garden: the legacy of humanism. Princeton: Princeton University Press. 2002.).

${ }^{4}$ DE SOUZA, Leonardo Cruz et al. A poética de Augusto dos Anjos e a neuropsiquiatria no fin de siècle. História, Ciências, Saúde-Manguinhos, v.25, n.1, p.163-179. 2018. 
e Lima Barreto. Tamano et al. ${ }^{5}$ estudaram a presença de princípios associados às teorias raciais em autores como Aluísio Azevedo e Graça Aranha, que inseriram discussões semelhantes em 0 Cortiço (1890) e Canaã (1902), por exemplo.

O Brasil passava por uma transformação institucional, e os sentidos de identidade provenientes do contexto imperial eram cada vez mais questionados, por vezes rechaçados como símbolos do atraso. Na República, uma nova identidade deveria ser erigida, e os homens de letras entendiam-se como responsáveis por esse processo. ${ }^{6}$ Exemplo concreto dessas mudanças é a defesa de um nacionalismo racional por Lobato, em oposição à postura romântica de José de Alencar. ${ }^{7}$ Como afirmou em carta ${ }^{8}$ ao amigo Godofredo Rangel, ${ }^{9}$ o patriotismo apaixonado esconde as verdades sobre a nação (LOBATO, 1961b). Retratando uma mudança de referenciais, o autor defendia que o Brasil precisava tomar, em vez da Europa, os Estados Unidos como modelo central para o seu desenvolvimento. O empreendimento de homens como Henry Ford (1863-1947) era o projeto ideal de uma cultura da eficiência (LOBATO, 1966).

As temáticas encontradas nos escritos de Lobato são diversificadas. Na década de 1910, o autor concentrou sua pena na problemática do homem nacional, representado pelo Jeca Tatu. Os textos centrais dessa discussão foram publicados em 1914, no jornal O Estado de S. Paulo. Em Velha praga e Urupês, presentes na obra que traz este último por nome (LOBATO, 2014b), Monteiro Lobato teceu uma descrição ácida da figura do caboclo. Esses artigos são compostos de concepções deterministas e pessimistas sobre o futuro do país, porém, apesar de relacionados à mentalidade cientificista, não encontramos neles menções diretas ao pensamento eugenista. Em "O presidente negro", de 1926, por outro lado, o discurso torna-se explícito, e, por meio da narrativa ficcional, o leitor é capaz de visualizar a "perfeição" de um mundo onde os princípios morais são abandonados em nome do progresso (LOBATO, 1956b).

\footnotetext{
5 TAMANO, Luana Tieko Omena et al. O cientificismo das teorias raciais em O cortiço e Canaã. História, Ciências, Saúde-Manguinhos, v.18, n.3, p.757-774. 2011.
}

${ }^{6}$ SEVCENKO, Nicolau. Literatura como missão: tensões sociais e criação cultural na primeira República. 4. ed. São Paulo: Brasiliense. 1995.

7 CAVALHEIRO, Edgard. Monteiro Lobato... Op. cit.

8 Destaca-se aqui a importância das cartas de Monteiro Lobato como fonte primária. Como aclara Emerson Tin, as cartas são uma forma de apreender as múltiplas personalidades de Lobato: escritor, marido, revolucionário, editor etc. (Cf. TIN, Emerson. Em busca do "Lobato das cartas": a construção da imagem de Monteiro Lobato diante de seus destinatarios. 2007. Tese (doutorado) - Universidade Estadual de Campinas, Instituto de Estudos da Linguagem, Campinas, SP, 2007). No mais, a análise desses documentos precisa considerar que Lobato pensava as suas cartas como um meio de intervenção, uma vez que investiria nas publicações desse material desde 1910. Rômulo Pinto de Souza destaca, igualmente, a importância das cartas para pensar as interpretações de Lobato sobre a identidade nacional e as suas diferenças mais acentuadas com as ideias defendidas por outros intelectuais no período. SOUZA, Rômulo Pinto de. Tradução, ordenação e reescrita: um Hans Staden à brasileira ou Lobato, um leitor do Brasil?. Dissertação (Mestrado em Letras) - Universidade Federal Fluminense, Niterói, 2013.

9 José Godofredo de Moura Rangel (1884-1951), amigo com quem Lobato manteve mais de quatro décadas de correspondência, foi membro do cenáculo, composto por, além dos dois amigos, Lino Moreira, Tito Lívio Brasil, Albino Camargo, Cândido Negreiros, Raul de Freitas e José Antonio Nogueira. Assim como os outros membros, Rangel era formado em Ciências Jurídicas e um escritor bastante elogiado por Lobato, em suas qualidades literárias. NOGUEIRA, Eloisa Alves. O eu e o outro: o legado de dois pais contado por Machado de Assis e Godofredo Rangel. Dissertação (Mestrado em Literatura Brasileira) - Universidade Federal de Juiz de Fora, Juiz de Fora, 2017. 
Conteúdo semelhante é encontrado no livro América, de 1932. Retomando um protagonista delineado já em 1927, na obra Mister Slang e o Brasil, Lobato (1966) detalha um diálogo entre o narrador e Mister Slang. A personagem, caracterizada como um culto cidadão inglês, destaca-se por seu senso crítico e sua autonomia intelectual. A inteligência e a superioridade de sua figura são repetidamente trazidas à tona durante as conversas. $O$ texto gira em torno de comparações entre Brasil e Estados Unidos, ${ }^{10}$ este último sendo o cenário do encontro entre as personagens em Mister Slang e o Brasil. Os discursos ficcionais de América fornecem mais pistas a respeito da presença de preceitos eugenistas nas linhas lobatianas, sugerindo, quando cruzados com outras fontes, certas consistências entre o pensamento do autor e o conteúdo das obras.

A eugenia, fundada pelo naturalista inglês Francis Galton, é uma autointitulada ciência preocupada em promover a reprodução de indivíduos considerados, de acordo com características - afixadas por alguns cientistas - superiores, e em desincentivar a propagação daqueles vistos como inferiores. Galton definiu-a como "a ciência do melhoramento da linhagem". ${ }^{11}$ Ao longo da segunda metade do século XIX e da primeira parte do século XX, diferentes atores apropriaram-se dessa teoria, lançando sobre ela interpretações particulares. Em seus resultados mais trágicos, associada a outros movimentos de apelo similar, esteve envolvida não só com a esterilização compulsória de centenas de milhares de seres humanos, mas também com a perseguição e execução de outros milhões, como ocorreu no regime nazista. ${ }^{12}$

O texto a seguir procura demonstrar que ideais e princípios associados à eugenia estão presentes de diferentes maneiras nos vários escritos lobatianos. Podemos identificar passagens em que os princípios científicos de manipulação hereditária são explicitamente chamados à cena, ligados a elementos de um evidente preconceito racial. A análise das fontes, no entanto, não permite que afirmemos que o projeto de Brasil construído pelo escritor paulista tinha esse fundamento como linha mestra. Apesar de navegar pelos mares eugenistas, foi na transformação das condições do meio, pela luta contra a pobreza, pela modernização industrial e agrícola, bem como pelo combate às doenças e ao atraso educacional, que o escritor paulista vislumbrou o florescer de uma nação brasileira.

\footnotetext{
10 Míriam Porfírio da Silva (2018) identifica uma forte defesa do modelo estadunidense na obra de Lobato. América seria escrito após o retorno do autor desse país em 1932 e traria como um dos seus objetivos denunciar o atraso brasileiro, destacando a subserviência a outros países e a dependência em relação à exportação de produtos primários. Lobato se colocava aqui como um defensor das ideias de progresso e modernização.

${ }^{11}$ GALTON, Francis. Inquiries into human faculty and its development. Nova York: MacMillan and Co. 1883, p. 25.

12 BLACK, Edwin. A guerra contra os fracos: a eugenia e a campanha dos Estados Unidos para criar uma raça dominante. São Paulo: A Girafa. 2003. O pensamento eugenista, apesar de sua faceta genocida exposta pela Alemanha nazista, não se limitou à perpetuação de violências desse tipo, ganhando diferentes contornos e nuanças nos diferentes espaços em que foi apropriado. Essa perspectiva, no Brasil, serviu também como forma de impulsionar reformas básicas na saúde pública.
} 


\section{Um Brasil exposto ao Laboratório}

O exercício da ciência formal no Brasil tem suas raízes na vinda da família real portuguesa, em $1808 .{ }^{13}$ No período subsequente à independência, o saber científico passou a ser direcionado aos interesses próprios da realidade local. Em 1838, o Instituto Histórico e Geográfico Brasileiro foi criado e consolidou certa história nacional. ${ }^{14}$ No Segundo Reinado (1840-1889), sob os auspícios de Dom Pedro II, novas instituições de pesquisa começaram a se fortalecer. A respeito da inserção do cientificismo no cenário brasileiro, Schwarcz afirma: "Esse tipo de discurso evolucionista e determinista penetra no Brasil a partir dos anos 1870 como um novo argumento para explicar as diferenças internas". Como resultado, "era a partir da ciência que se reconheciam diferenças e se determinavam inferioridades". ${ }^{15}$

No século XIX, o Brasil foi destino de intelectuais ligados às teorias degeneracionistas. Essa corrente disseminou uma visão incrédula quanto à possibilidade civilizacional nos países muito diversos etnicamente. O conde francês Arthur de Gobineau (1816-1882) e o cientista suíço Louis Agassiz (1807-1973), por exemplo, nomes fortes do racismo científico moderno, relataram de maneira dura algumas de suas impressões sobre o território e seus habitantes. Como afirma Diwan, ${ }^{16}$ esses homens tornaram-se referências legitimadoras para alguns dos cientistas brasileiros que aceitavam a desqualificação da população mestiça nacional.

A Faculdade de Medicina de Salvador foi um dos principais centros de produção de pesquisas ligadas às teorias raciais. O médico brasileiro Raimundo Nina Rodrigues (1862-1906) teve papel fundante na propagação dos estudos sobre a formação da população nacional. Para muitos dos acadêmicos que orbitavam nesse núcleo, "a mistura proporcionava a loucura, a criminalidade e a doença". ${ }^{17}$ Outros intelectuais, a exemplo de João Batista de Lacerda, Sílvio Romero e Afrânio Peixoto, porém, não enxergavam dessa maneira e, partindo do pressuposto de que a miscigenação levava ao aprimoramento da chamada raça inferior, estipulavam diferentes prazos para que a mistura gerasse o efeito desejado: o branqueamento da população. ${ }^{18}$

\footnotetext{
13 SCHWARCZ, Lilia Moritz. O espetáculo das raças: cientistas, instituições e questão racial no Brasil; 18701930. São Paulo: Schwarcz. 2004; STEPAN, Nancy Leys. Eugenia no Brasil, 1917-1940. In: HOCHMAN, Gilberto; ARMUS, Diego (Orgs.). Cuidar, controlar, curar: ensaios históricos sobre saúde e doença na América Latina e Caribe. Rio de Janeiro: FIOCRUZ. p.331-391. 2004; DIWAN, Pietra. Raça Pura. São Paulo: Contexto. 2007.

14 SCHWARCZ, Lilia Moritz. O espetáculo das raças... Op. cit.

${ }^{15}$ Ibidem, p. 38.

16 DIWAN, Pietra. Raça Pura. São Paulo: Contexto. 2007.

${ }^{17}$ Ibidem, p. 91.

18 SKIDMORE, Thomas E. Black into white: race and nationality in Brazilian thought. Durham: Duke University Press Books. 1992.
} 
No Rio de Janeiro ascendiam as medidas sanitaristas ${ }^{19}$ e higienistas, representadas pela liderança do médico Oswaldo Cruz (1872-1917). Como argumentam Lima e Hochman, ${ }^{20}$ o movimento sanitarista da Primeira República "teve um papel central e prolongado na reconstrução da identidade nacional a partir da identificação da doença como o elemento distintivo da condição de ser brasileiro". Os médicos envolvidos nos embates nacionalistas apontavam para o descaso político com relação à situação da população, principalmente rural, que estava abandonada. Assim, a reforma da saúde pública foi revigorante, fundamental à mentalidade de uma relevante parcela dos responsáveis por pensar a República. ${ }^{21}$

Nesse contexto, ganhou força o movimento eugenista. Encabeçado sobretudo por médicos que se viam como responsáveis pela habilitação do progresso no Brasil, tal movimento materializou-se institucionalmente em 1918, com a fundação da Sociedade Eugênica de São Paulo, sob liderança do médico e farmacêutico Renato Ferraz Kehl (1889-1974). ${ }^{22}$ Apesar de a sociedade ter sido dissolvida já em 1919, os mais de cem membros evidenciavam o interesse de parte da elite pelo tema. ${ }^{23}$ A Liga Pró-Saneamento do Brasil foi também uma significativa organização nacional, plataforma de luta pela reforma sanitária, congregando interesses de vários intelectuais, como os médicos Belisário Penna (1868-1939) e Artur Neiva (1880-1943), além do renomado protozoólogo Carlos Chagas (1879-1934).

Outra importante associação nesse segmento foi a Liga Brasileira de Higiene Mental, ${ }^{24}$ fundada em 1922 pelo neurologista e psiquiatra Gustavo Riedel (1887-1934). Em seu estatuto, a liga declarava que seu objetivo era a "realização de um programma de Hygiene Mental e de

19 É importante notar que se desenvolveram no Brasil diferentes e obtusas perspectivas sobre sanitarismo e eugenismo. Para Nancy Leys Stepan (2005), o movimento eugênico que se espraiou por diversos países não pode ser considerado unitário, uma vez que diferentes correntes surgiram e se adaptaram no processo de circulação de ideias. A incursão feita pela autora nos diferentes espaços que sofreram a influência das ideias eugenistas aponta para uma diferença entre os países anglo-saxônicos e os latino-americanos, marcados respectivamente por uma influência mais próxima das teorias mendelianas e neolamarckianas de hereditariedade. Decorrente dessa divisão de pensamento, vemos surgir nos países-latino-americanos a chamada "eugenia preventiva" - vinculada mais fortemente às reformas sociais e às políticas em prol da higiene e do saneamento do que das questões biológicas. Ao propor uma linha distinta da "eugenia negativa anglo-saxônica", esses atores criaram respostas que se adaptavam as suas visões religiosas, políticas e sociais no processo de transmigração de ideias, gerando um projeto com características próprias.

20 LIMA, Nísia Trindade; HOCHMAN, Gilberto. Condenado pela raça, absolvido pela medicina: o Brasil descoberto pelo movimento sanitarista da Primeira República, p. 23. In: Maio, Marcos Chor; Santos, Ricardo Ventura (Orgs.). Raça, ciência e sociedade. Rio de Janeiro: FIOCRUZ. p.23-40. 1996.

${ }^{21}$ HOCHMAN, Gilberto; LIMA, Nísia Trindade. "Pouca saúde e muita saúva": sanitarismo, interpretações do país e ciências sociais. In: Armus, Diego; Hochman, Gilberto (Orgs.). Cuidar, controlar, curar: ensaios históricos sobre saúde e doença na América Latina e Caribe. Rio de Janeiro: FIOCRUZ. p.493-534. 2004.

22 Interessa notar que Renato Kehl foi um dos membros do movimento eugênico no Brasil que mais se aproximou da eugenia negativa. Segundo Alessandra Rosa (2005), Kehl deixava claro que a hereditariedade era responsável pela constituição dos indivíduos, negando a possibilidade de recuperação pela adoção dos preceitos defendidos pelos sanitaristas. As suas ideias pautaram-se pelo controle dos casamentos dos "indivíduos aptos", o convencimento dos chamados indivíduos disgênicos de não terem filhos e de um projeto de imigração que atendesse os preceitos e parâmetros ideias de sociedade proposto pelo movimento eugênico - propiciando assim o crescimento do país.

23 STEPAN, Nancy Leys. Eugenia no Brasil... Op. cit.

${ }^{24}$ Idem. 
Eugenetica no domínio das atividades individual, escolar, profissional e social".25 Entre os problemas que propunha solucionar, estavam "os perigos que a doença mental e a 'patologia' dos pobres - crime, delinquência e prostituição - representavam para a sociedade". ${ }^{26}$

Veículos de imprensa davam espaço para os discursos dos proeminentes cientistas. Jornais e folhetos próprios, como os Annaes de Eugenía, de propriedade da Sociedade Eugênica, e o Boletim de Eugenia, lançado por Kehl em 1929, também abriam caminhos para a propaganda desses pensamentos. ${ }^{27} \mathrm{O}$ impulsionamento do progresso nacional era de interesse do público leitor, formado pelos "elementos cultos" brasileiros, como escreveu Kehl ${ }^{28}$ na edição inaugural do boletim. Vale notar, contudo, que não havia homogeneidade nas discussões entre os divulgadores do pensamento eugenista. No fim da década de 1920, as divergências tornaramse mais claras.

O Primeiro Congresso Brasileiro de Eugenia foi realizado em 1929 e "representou uma ofensiva pública e direta em defesa da causa eugenista como nunca antes. Seu principal objetivo era definir através de consensos quais seriam as propostas para políticas públicas para o governo". ${ }^{29}$ Poucos foram, no entanto, os consensos encontrados. Isso porque, a exemplo do pensamento eugenista no mundo, ${ }^{30}$ diferentes olhares sobre a matéria acabavam promovendo debates acirrados a respeito do caminho mais adequado para a vitória desse projeto. No Brasil, uma das discussões abrangia os vieses positivo, negativo e preventivo da eugenia. O primeiro visava incentivar casamentos entre pessoas de boa constituição física e mental, o segundo tinha como propósito desestimular a reprodução de pessoas inferiores, e o terceiro intencionava propagar desde medidas de educação eugênica, até reformas estruturais. ${ }^{31}$ Esse último modelo aproximava-se de maneira bastante nítida do pensamento higienista, e congregava os que acreditavam em um futuro possível para a população miscigenada.

Um dos principais embates da história da eugenia no Brasil foi travado entre Renato Kehl e o médico e antropólogo Edgard Roquette-Pinto (1884-1954). Os dois intelectuais partiam de uma premissa idêntica: a eugenia deveria ser pensada com base na genética de Mendel. ${ }^{32}$ Como

25 LIGA BRASILEIRA DE HYGIENE MENTAL. Estatutos da Liga Brasileira de Hygiene Mental. Archivos Brasileiros de Hygiene Mental, v.1, n.1, p.223-234. 1925, p. 223.

26 STEPAN, Nancy Leys. Op cit, p. 343.

27 Ibidem, p. 345.

${ }^{28} \mathrm{KEHL}$, Renato. O nosso boletim. Boletim de Eugenia, v.1, n.1. 1929a, p. 1.

29 DIWAN, Pietra. Op. cit, p. 113.

30 TURDA, Marius. Modernism and eugenics. Nova York: Palgrave MacMillan. 2010

31 SOUZA, Vanderlei Sebastião de. A política biológica como projeto: a eugenia negativa e a construção da nacionalidade na trajetória de Renato Kehl (1917-1932). Dissertação (Mestrado em História das Ciências e da Saúde) - Casa de Oswaldo Cruz, Fundação Oswaldo Cruz, Rio de Janeiro, 2006. Disponível em: <https://www.arca.fiocruz.br/handle/icict/6134>. Acesso em: 12 maio. 2018.

32 Gregor Mendel (1822-1884) é um dos responsáveis pelo desenvolvimento da genética moderna. Para ele, apesar de haver uma combinação entre o material humano dos pais, sua composição é alocada de maneira variada na prole. Essa alocação permite, por exemplo, que traços se escondam durante gerações até que se manifestem. (Cf. TURDA, Marius. Modernism and eugenics. Nova York: Palgrave MacMillan. 2010). 
escreve Souza, "os eugenistas mendelianos postulavam que o material hereditário seguia leis independentes da influência do meio, sendo transmitido apenas [...] por meio da célula germinal". ${ }^{33}$ Ainda assim, Roquette-Pinto e Kehl chegavam a conclusões opostas. Por um lado, o farmacêutico entendia que era necessário que o Estado controlasse a reprodução de seus cidadãos e amplamente vetasse, por conta do potencial destrutivo da mistura racial, a entrada de certos grupos de imigrantes. Por outro, o antropólogo defendia que a miscigenação brasileira não estava associada à degradação racial ${ }^{34}$ e propunha menos restrições para a imigração.

No trabalho que apresentou no congresso, Roquette-Pinto explicitou sua posição, revelando uma crítica à ideia de que a miscigenação gera, por si só, indivíduos inferiores. De acordo com ele, "tem-se o hábito de considerar degenerados, mestiços que são apenas doentes ou dysgenicos. Não é o cruzamento; é a doença a causa do aspecto débil de muitos deles". 35 Também afirmou o autor, nesse artigo, que não existem diferenças intelectuais entre brancos e negros e que, expostos às mesmas condições sociais, ambos têm o mesmo desenvolvimento. Roquette-Pinto conclui: "O problema das raças não existe no Brasil". ${ }^{36}$ Sua postura contrastava com a de Kehl.

Fundamentado em estudos eugenistas, Kehl assegurava que medidas educacionais, investimentos em higiene, e outras mudanças ambientais, eram inócuas quando isoladas. Apesar de esses elementos se configurarem como ferramentas úteis para o desenvolvimento e o progresso social, ele acreditava ser necessário "ter em conta tambem a alavanca mestra do progresso biológico que é a aplicação das leis da hereditariedade, segundo os preceitos da eugenia". ${ }^{37}$ Apelando para os eventos bárbaros que tinham, havia pouco, tomado o mundo, como a Primeira Guerra Mundial, ele dizia:

\begin{abstract}
Estes factos demonstram que a educação e as injuncções religiosas não bastaram para moderar as paixões, para tornar a humanidade melhor, mais equilibrada, mais filantrópica. Isto porque o homem continuou escravo de sua natureza particularíssima, indelével a simples influencias moraes e mentaes, preso a uma força que o subjuga biologicamente, que Ihe imprime o temperamento, o caracter, de modo inexorável, a hereditariedade. ${ }^{38}$
\end{abstract}

Na prática, os esforços eugenistas resultaram na criação de algumas legislações. Suas principais conquistas legais ocorreram nos anos que cercam o primeiro governo de Getúlio Vargas (1930-1945). Nas constituições de 1934 e 1937, apesar de certa flutuação, foram

\footnotetext{
33 SOUZA, Vanderlei Sebastião de. As idéias eugênicas no Brasil: ciência, raça e projeto nacional no entreguerras. História em Reflexão, v.6, 2012, p. 14.

${ }^{34}$ SOUZA, Vanderlei Sebastião de. A eugenia brasileira e suas conexões internacionais: uma análise a partir das controvérsias entre Renato Kehl e Edgard Roquette-Pinto, 1920-1930. História, Ciências, SaúdeManguinhos, v.23, n.1, 2016, p. 100.

35 ROQUETTE-PINTO, Edgard. Notas sobre os typos anthropologicos do Brasil. In: Couto, M. (org.). Primeiro Congresso Brasileiro de Eugenia: Actas e Trabalhos. Rio de Janeiro. p.119-148. 1929, p. 136.

${ }^{36}$ Ibidem, p. 138, grifo do autor.

$37 \mathrm{KEHL}$, Renato. A eugenia no Brasil. In: Couto, M. (Org.). Primeiro Congresso Brasileiro de Eugenia: Actas e Trabalhos. Rio de Janeiro. p.45-62. 1929c, p. 48.

38 Ibidem, p. 47.
} 
inseridas medidas ao estímulo da educação eugênica, à educação física, a cotas raciais para imigração etc. ${ }^{39} \mathrm{Na}$ década de 1930, o movimento eugenista começou a perder força, entre outros motivos, graças ao crescimento de influências do culturalismo de Franz Boas (18581942), que foi adotado por Gilberto Freyre (1900-1987) e até mesmo por Roquette-Pinto. ${ }^{40}$ Ainda durante o congresso, Boas foi utilizado como referência intelectual contrária à discriminação racial.

A exposição dos crimes nazistas na década de 1940, bem como a ascensão de pesquisas antropológicas com novas abordagens sobre a população negra e rural brasileira, garantiu o gradual abandono do racismo científico predominante nos espaços de construção de conhecimento. ${ }^{41}$ A categoria "raça", embora não tivesse sido retirada das discussões, passava a ser tratada com outro olhar, mais positivo, identificando potencialidades na composição mestiça nacional, numa tentativa de valorizar a constituição demográfica local. ${ }^{42}$

O debate entre diferentes perspectivas e meios de ação do movimento eugenista brasileiro não é, como se percebe, sinal de fraca participação de seus partidários nas discussões nacionais. As divergências indicam uma complexa articulação de diversos projetos construídos por esses intelectuais. Se, por um lado, não se pode encontrar homogeneidade, por outro é possível vislumbrar o entrelaçamento dos diferentes movimentos interessados na saúde pública. Sanitaristas, higienistas e eugenistas configuravam, nesse sentido, um conjunto de intelectuais com o objetivo de construir o Brasil. Nesse grupo estava Monteiro Lobato.

\section{O homem e seu tempo}

As reflexões de Lobato sobre a problemática racial começaram ainda em sua juventude. ${ }^{43}$ Os textos concentrados em Literatura do Minarete giram em torno de seu tempo como estudante de Direito, entre 1900 e 1904. Para o jovem escritor, o Brasil, "filho de pais inferiores", é "incapaz

\footnotetext{
39 STEPAN, Nancy Leys. Op cit, p. 343.

40 DIWAN, Pietra. Op. cit. A influência de Boas em Roquette-Pinto é seletiva, conforme argumenta SOUZA, Vanderlei Sebastião de. Em busca do Brasil: Edgard Roquette-Pinto e o retrato antropológico brasileiro (1905-1935). Tese (Doutorado em História das Ciências e da Saúde) - Casa de Oswaldo Cruz / Fiocruz, Rio de Janeiro, 2011. $382 \mathrm{f}$.

${ }^{41}$ SKIDMORE, Thomas E. Black into White... Op. cit.

42 SOUZA, Vanderlei Sebastião de. As idéias eugênicas no Brasil... Op. cit, p. 16.

43 José Wellington de Souza (2017) defende que existem alterações expressivas nas ideias expressas por Monteiro Lobato se colocarmos em confronto as primeiras e últimas obras publicadas pelo autor. Souza tem razão ao defender a importância na obra do autor do peso das mudanças econômicas do Brasil e, principalmente, dos espaços de poder ocupados por Lobato nos anos entre 1900 e 1947 . A decadência do Vale do Paraíba e os problemas econômicos e sociais oriundos da situação familiar do autor impactaram na percepção da sociedade e no projeto nacional idealizado por Lobato. Do mesmo modo, as suas leituras posteriores do Brasil sofreram progressivas mudanças geradas pela nova condição social ocupada pelo autor - que passa a fazer parte da elite, assumindo melhores cargos públicos e alcançado o status de escritor e editor profissional. Ademais, as mudanças no pensamento médico-racial e o fortalecimento da medicina nas diversas esferas de poder tiveram um peso significativo na postura defendida por Lobato nas diferentes fases da sua obra.
} 
de continuar a se desenvolver sem o concurso vivificador do sangue dalguma raça original" (LOBATO, 1961c, p. 110). Ao comentar sobre o futebol, Lobato atribui ao esporte o papel de "estimulante mais poderoso que entre os fortes estimulantes encontra o sangue anglo-saxão" (LOBATO, 1961c, p. 179). A atividade física, para ele, era promotora de energia moral e estimulava as características que fariam da raça inglesa um tipo superior em relação à raça latina, que é "degenerada e gasta" (LOBATO, 1961c, p. 181). Lembramos que o incentivo ao exercício corporal é parte fundamental da educação eugênica. ${ }^{44}$

Em 1905, em carta enviada ao amigo Tito Lívio Ferreira, o autor demonstrava crer naquilo que fora descrito por Galton (1892): os aspectos morais eram tão hereditários quanto os traços físicos. O filho do negro possui a pele negra e, assim, dará continuidade aos comportamentos típicos de sua raça. Para o escritor paulista, "um só sangue mais elevado, um sangue de raça mais superior, poderá transfundir nos entes novos o germe da progressividade" (LOBATO, 1964a, p. 76). Tal noção de aquisição da progressividade por meio do sangue, revela a crença no branqueamento: "Só a emigração e a consequente fusão de sangue superior trará uma aptidão congênita para o progresso" (LOBATO, 1964a, p. 76). Ao longo de seus textos, como veremos, não há uma posição estável quanto a essa doutrina.

Ao amigo Godofredo Rangel, em 1907, revelaria a cena proporcionada pela Semana Santa em Taubaté: "Por toda parte, povo - o nosso povo, essa coisa feia, catinguenta e suada. Sovacos ambulantes" (LOBATO, 1961a, p. 157). Dois anos mais tarde, também ao amigo escreveria: "Eu gosto muito dos negros, Rangel. Parecem-me tragedias biologicas. Ser pigmentado, como é tremendo!" (LOBATO, 1961a, p. 244). É ainda ao mesmo destinatário que Lobato manifesta uma ideia seminal: "Vou ver se consigo escrever um conto, o Porrigo decalvans, em que considerarei o caboclo um piolho da terra, uma praga da terra" (LOBATO, 1961a, p. 327, grifo do autor). Lobato cumpriu sua palavra e em 1914 lançou Velha praga e Urupês, nas páginas do jornal O Estado de S. Paulo.

Esses textos constituem o cerne da famosa leitura lobatiana sobre o caboclo, ou o Jeca, que representa o morador das margens do Rio Paraíba do Sul (LOBATO, 2014b). Os artigos de Lobato trazem uma visão bastante pessimista sobre esses indivíduos e caracterizam-nos como seres improdutivos, sem cultura, preguiçosos e que fogem do progresso. Nessa situação, o caboclo, como "quantidade negativa", acaba não sendo capaz de compor uma classe adequada de trabalhadores: "Pelo Treze de Maio, mal esvoaça o florido decreto da Princesa e o negro exausto larga num uf! o cabo da enxada, o caboclo olha, coça a cabeça, imagina e deixa que do velho mundo venha quem nele pegue de novo" (LOBATO, 2014b, p. 171, grifo do autor).

A referência feita aqui à assinatura da Lei Áurea como data na qual os negros, antes escravizados, teriam abandonado o trabalho, chama a atenção. Essa ideia sugere uma percepção de que aqueles homens e mulheres, agora desobrigados a trabalhar de forma compulsória, se entregavam à vadiagem, abandonando sua função no campo. Se o negro era feito para o

\footnotetext{
${ }^{44}$ BLACK, Edwin. A guerra contra os fracos... Op. cit.
} 
trabalho e o caboclo avesso a essa prática, a solução para a produtividade nacional só poderia vir de fora, do europeu.

Em 1918, Lobato reuniria sua percepção do caboclo no livro "Urupês". Outros escritos, incluídos também nessa coleção, podem ser aqui trazidos à luz. Em "Bocatorta", de 1915, um negro deformado fisicamente é revelado como culpado de necrofilia. O desvio moral ligado a aspectos orgânicos pode ser visto ainda no conto "Mata-Pau", do mesmo ano, no qual um jovem acaba se relacionando intimamente com sua mãe adotiva, por "má índole congenial" (LOBATO, 2014b, p. 120). "A Policitemia de Dona Lindoca", "Barba Azul" e "O Fisco", reunidos em "Negrinha" (LOBATO, 2014a), são outros exemplos de textos em que a presença de termos médico-biológicos é preponderante.

O título do compêndio "Urupês" foi sugestão de Artur Neiva, sanitarista amigo de Lobato. ${ }^{45}$ Essa amizade com o cientista, que era discípulo de Oswaldo Cruz, somada à leitura dos relatórios sobre as condições de vida da população brasileira, fez com que Lobato revisasse sua leitura do caboclo e Ihe dedicasse uma visão esperançosa, calcada na possibilidade de tirálo da miséria por meio da recuperação de sua saúde. É relembrando uma visita que fez a Iguape, na companhia de Neiva, que o escritor tenta, em um dos artigos da coletânea Problema vital (1918), desvencilhar o problema brasileiro da configuração demográfica: "Não é a raça - a raça dos bandeirantes é a mesma de Jéca Tatú. É um longo e ininterrupto estado de doença transmitido de pais a filhos e agravado dia a dia" (LOBATO, 1956a, p. 306).

Ao mesmo tempo em que se juntava às fileiras sanitaristas, Lobato iniciava seu contato com Renato Kehl, tratando-o como "espírito brilhante" e "untado para nobres ideaes" (LOBATO, 1918). Lobato comentava sobre a leitura que fez de uma palestra ministrada pelo farmacêutico no ano anterior. Nessa oportunidade, Kehl defendeu que é preciso ir além do sanitarismo, já que é a raça que precisa ser tratada. O médico sugeriu a "seleção conjugal, efetuada com critério, regra e inteligência", ${ }^{46}$ e separou a saúde em duas áreas: higiene e eugenia. A primeira serviria para "afastar as causas dos males", e a segunda, para selecionar os indivíduos, de modo a formar uma unidade racial. Em correspondência posterior, Lobato admitiu ao cientista: "Tu és o pae da Eugenía no Brasil [...]. Precisamos lançar, vulgarizar essas ideas. A humanidade precisa de uma coisa só: póda. É como a vinha" (LOBATO, [1926 ou 1927]).

$\mathrm{Na}$ primeira carta que enviou ao farmacêutico, o escritor deu seu consentimento ao pedido da Sociedade Eugênica para a edição e publicação do livro Problema vital. Pode-se supor que Kehl pretendia, ao publicar os textos de Lobato, além de associar publicamente a sociedade ao nome do escritor, estimular a campanha da saúde pelo viés da higiene, sustentando sua relação também com os sanitaristas, que gozavam de respeito no país. Não à toa, a primeira edição de Problema vital deu-se em parceria com a Liga Pró-Saneamento do Brasil. Há certo

\footnotetext{
45 CAVALHEIRO, Edgard. Monteiro Lobato... Op. cit.

46 KEHL apud SANTOS, Ricardo Augusto dos. O manifesto eugenista. In: Penna, Antonio Gomes (Org.). Manifestos Políticos do Brasil Contemporâneo. Rio de Janeiro: E-Papers, 2008, p. 61.
} 
consenso sobre diferentes fases de Renato Kehl, que, a partir de fins da década de 1920, passaria a fomentar medidas com foco na raça, distanciando-se do sanitarismo hegemônico. ${ }^{47}$

Os textos que Lobato publicou em 1918 estavam diretamente associados aos que foram lançados por Belisário Penna entre 1916 e 1917 (LOBATO, 1956a, p. 237). O sanitarista afirmava que "uma viagem atravéz dos nossos sertões, e mesmo fóra delles, confrange a alma e abate a confiança no futuro da pátria, sobretudo pela indifferença ou inconsciencia dos poderes públicos". 48 Mas havia esperança. Ao lado dos sanitaristas, Lobato (1956a, p. 298) declarava: "Respiramos hoje com mais desafogo. O laboratorio dá-nos o argumento por que ansiavamos. Firmados nele contraporemos á condenação sociologica de Le Bon a voz mais alta da biologia".

Essa oposição à conclusão pessimista de Le Bon e dos degeneracionistas não foi permanente em Lobato. Como demonstra a historiadora Stepan, ${ }^{49}$ os imbricamentos entre eugenistas e sanitaristas são bastante complexos e estimularam certa volatilidade entre os intelectuais. Conforme sustenta Campos, ${ }^{50}$ apesar de ter deslocado o problema do caboclo da esfera racial, a dualidade é insistente na escrita do autor, que ora motiva uma crítica à situação social da população, ora estimula um olhar ligado às teorias racistas hegemônicas.

\section{Um romance eugenista}

Entre 1918 e 1926, Monteiro Lobato concentrou suas atividades na condução da Revista do Brasil, da qual era dono. Seus escritos popularizavam-se, principalmente pelo acesso à máquina editorial. A figura do Jeca Tatu ganhou, em março de 1919, a atenção de Ruy Barbosa (1849-1923) e exigiu ainda mais impressões. Com sua presença fixada no grupo dos mais influentes escritores do país, o autor receberia um convite do governo para operar como adido comercial em Nova York, para onde se mudou em junho de 1927. Entre seu desembarque e o retorno ao Brasil, Lobato entrou em contato com diversas inovações tecnológicas e encantou-se com o que as indústrias do ferro e do petróleo poderiam fazer pelo país. ${ }^{51}$

Antes de se mudar para os Estados Unidos, o autor escreveu "O choque das raças", ou "O presidente negro". "Tirei o mez de Julho para escrever um romance americano que me pediu um publisher de lá. Fil-o em 20 dias, ao correr da penna, e aproveitando uma velha idéa que um dia Ihe comuniquei", escreveu Lobato ([1926]) ao médico Artur Neiva. Na mesma carta, informou que pretendia dedicar esse livro ao amigo e pediu a opinião dele sobre seu conteúdo.

\footnotetext{
47 STEPAN, Nancy Leys. Eugenia no Brasil... Op. cit.; SOUZA, Vanderlei Sebastião de. As idéias eugênicas no Brasil... Op. cit.

48 PENNA, Belisário. Saneamento dos sertões I. Correio da Manhã, p.2. 1916.

49 STEPAN, Nancy Leys. Op. cit.

50 CAMPOS, André Luiz Vieira de. A República do Picapau Amarelo: uma leitura de Monteiro Lobato. São Paulo: Martins Fontes. 1986.

51 CAVALHEIRO, Edgard. Op. cit.
} 
Nota-se que, posteriormente, o escritor paulista iria confessar a Renato Kehl que deveria ter dedicado o seu "grito de guerra pró-eugenía" a ele (LOBATO, [1926 ou 1927]).

Como se observa em sua correspondência, o escritor tinha a intenção de publicar a obra e fundar uma editora nas terras mais ao norte (LOBATO, 1961b, p. 293). Em carta a Godofredo Rangel datada de 1927, o autor confessou, no entanto, que o sonho havia fracassado, por resistência das casas publicadoras: "Meu romance não encontra editor. Falhou a Tupy Company. Acham-no ofensivo á dignidade americana, visto admitir que depois de tantos seculos de progresso moral possa este povo, coletivamente, cometer a sangue frio o belo crime que sugeri. Errei vindo cá tão verde. Devia ter vindo no tempo em que eles linchavam os negros" (LOBATO, 1961b, p. 304).

Se foi o que de fato ocorreu, é notório que o conteúdo do livro tenha sido considerado ofensivo no país no exato ano em que o caso Buck vs. Bell foi julgado pela Suprema Corte. Nesse evento, com apenas um voto contrário, Carrie Buck, uma interna da Colônia Estatal de Virginia para Epiléticos e Débeis Mentais, foi condenada à esterilização compulsória. ${ }^{52} \mathrm{O}$ mesmo país que judicialmente aderia à eugenia, em termos morais parecia se opor a tais violações da dignidade humana. De acordo com Black, ${ }^{53}$ medidas como essas não eram bem-vistas pela população norte-americana, temerosamente consciente de sua formação étnica plural.

O livro "O presidente negro" foi o único romance publicado por Lobato. Seu enredo inicial é apenas pano de fundo para uma narrativa de visualização do futuro que coloca em cena uma sociedade estadunidense fragmentada, no campo político, em três grandes segmentos: o Partido Masculino, o Partido Feminino e o Partido Negro. Esse cenário corre no ano de 2228, e a personagem Ayrton ouve Miss Jane - filha do já morto inventor do "porviroscópio", máquina capaz de alcançar pontos distantes no futuro - descrever cada detalhe dessa história.

Por meio das personagens envolvidas na trama, Lobato elogia a lei seca norte-americana como sacrifício pelo bem da raça, ${ }^{54}$ engrandece os elementos europeus que colonizaram os Estados Unidos - que chama de "força vital da raça branca" (LOBATO, 1956c) - e critica a miscigenação ao expor o contraste entre a segregação americana e a assimilação racial brasileira:

\begin{abstract}
"A nossa solução foi mediocre. Estragou as duas raças, fundindo-as. O negro perdeu as suas admiraveis qualidades fisicas de selvagem e o branco sofreu a inevitavel peora de carater, consequente a todos os cruzamentos entre raças dispares. Carater racial é uma cristalização que ás lentas se vai operando através dos seculos. O cruzamento perturba essa cristalização, liquefa-la, torna-a instavel. A nossa solução deu mau resultado" (LOBATO, 1956c, p. 206).
\end{abstract}

\footnotetext{
52 ANTONIOS, Nathalie; RAUP, Christina. Buck v. Bell (1927). Disponível em: <https://embryo.asu.edu/pages/buck-v-bell-1927>. Acesso em: 4 abr. 2019. 2012.

53 BLACK, Edwin. Op. cit.

${ }^{54}$ É curioso notar que, apesar de criticar o consumo de álcool tanto na ficção, endossando a lei seca, quanto em seus textos sobre o Jeca (LOBATO, 2014b), Lobato menciona, por exemplo, em cartas a Artur Neiva, a realização de uma tradicional "choppada sabatina", além de não questionar o consumo de uísque por uma personagem que apresentaremos posteriormente, Mr. Slang (LOBATO, 1956b).
} 
Uma carta escrita com um teor curiosamente semelhante ao do excerto citado foi enviada a Rangel em 1908. Chama também a atenção a supressão desse trecho em edições posteriores de $\mathrm{A}$ barca de Gleyre, que reúne as cartas enviadas ao amigo. ${ }^{55}$ Escreve o autor: "O mulatismo dizem que trás dessoramento de caráter. Dizem que a mestiçagem liquefaz essa cristalização racial que é o caráter e dá uns produtos instáveis. Isso no moral - e no físico que feiúra!". ${ }^{56} \mathrm{O}$ escritor ainda aponta para o movimento dos moradores do subúrbio carioca, que, retornando para suas casas no fim do expediente, expõem o observador à visão de todo tipo de degenerescência.

Detalhe relevante é que Lobato indica que esse processo de "amulatização", ou "liquefação", é a "vingança" do negro. Nos Estados Unidos, ele escreve, não há esse problema, dado que a barreira do preconceito sustenta uma segregação sólida - que seria quase duas décadas depois incorporada à narrativa do livro aqui analisado. "Filosoficamente me parece horrível isto [a segregação racial] - mas certo do ponto de vista racial". ${ }^{57}$ A salvação para esse problema no Brasil poderia vir de São Paulo, destino dos imigrantes, que trariam sangue "superior". Ao mesmo tempo em que sugere que o cruzamento racial gera deformações físicas e de caráter, o autor aponta uma solução para esse problema por meio da entrada de sangue do Velho Mundo.

Relembrando Nietzsche, Miss Jane revela pensar para além do bem e do mal: "Não há mal nem bem no jogo das forças cósmicas" (LOBATO, 1956c, p. 207). Conclui: "O odio desabrocha tantas maravilhas quanto o amor. O amor matou no Brasil a possibilidade de uma suprema expressão biologica. O ódio criou na America a gloria do eugenismo humano..." (LOBATO, 1956c, p. 207). O uso do termo ódio para caracterizar a relação racial nos Estados Unidos chama a atenção, e pode ser colocado em perspectiva, se nos remetermos a uma carta enviada a Artur Neiva, em 1928:

Paiz de mestiços onde o branco não tem força para organizar uma Kux-Klan, é paiz perdido para altos destinos. André Siegfried ${ }^{58}$ resume numa phrase as duas attitudes. "Nós defendemos o front da raça branca - diz o Sul - e é graças a nós que os Estados Unidos não se tornaram um segundo Brazil." Um dia se fará justiça ao Klux Klan; tivessemos ahi uma defeza desta ordem, que mantem o negro no seu lugar, e estariamos hoje livres da peste da imprensa carioca - mulatinho fazendo o jogo do gallego, e sempre demolidor porque a mestiçagem do negro destróe a capacidade constructiva (LOBATO, 1928).

Em fins da década de 1920, é muito difícil argumentar que o autor, que já estava nos Estados Unidos, desconhecia as atrocidades e violências cometidas pelo grupo supremacista

\footnotetext{
55 ENDALÉCIO, Raquel Nunes. A (re)construção do mundo clássico na obra de Monteiro Lobato: fontes e procedimentos. Dissertação (Mestrado em Estudos Brasileiros) - Universidade de São Paulo, São Paulo. 2013. Disponível em: <https://bv.fapesp.br/pt/dissertacoes-teses/82668/a-re-construcao-do-mundoclassico-na-obra-de-monteiro-lobato>. Acesso em: 13 dez. 2019.

56 LOBATO, 1908 apud ENDALÉCIO, Raquel Nunes, Ibidem, p. 17;

57 Idem.

58 André Siegfried (1875-1959) foi um intelectual francês famoso por escrever sobre política e vida social na Grã-Bretanha e na América do Norte.
} 
citado. O fato de Lobato associar a incompetência da imprensa carioca à constituição racial de seus trabalhadores é um evidente sinal de racismo. Em um trecho imediatamente anterior ao exposto, podemos ler o termo "feeble-minded", usado para caracterizar indivíduos diagnosticados com doenças mentais, sobretudo no vocabulário eugenista. No caso Buck vs. Bell, que já mencionamos, ele é utilizado na sentença que condenou Carrie Buck à esterilização compulsória. ${ }^{59}$

$\mathrm{Na}$ narrativa distópica de $\mathrm{O}$ choque das raças, os negros haviam se submetido a tratamentos estéticos e, conforme sua cor de pele, eram todos igualmente brancos. O autor diz ainda que a maior vontade da população negra era trocar de cabelo, para assemelhar-se, enfim em totalidade física, ao branco. Além disso, as duas raças disputavam a melhor solução para o problema racial do país: dividi-lo geograficamente em dois, como propunham os primeiros, ou "exportar" todos os negros para o vale do Amazonas, ${ }^{60}$ como desejavam os últimos: "A permanencia no mesmo territorio de duas raças dispares e infusiveis perturbava a felicidade nacional" (LOBATO, 1956c, p. 238).

O autor menciona Francis Galton e indica que a elite pensante, nessa América futurista, aderiu aos princípios eugenistas, controlando a natalidade e evitando a reprodução desenfreada. Descreve, ainda, o funcionamento do Ministério da Seleção Artificial, órgão elaborado para zelar pela qualidade da raça. O argumento da personagem Miss Jane é:

\footnotetext{
"Entre cortar no inicio o fio da vida a uma posta de carne sem sombra de conciencia e deixar que dela sáia o ser conciente que vai vegetar anos e anos na horrivel categoria dos "desgraçados", a crueldade está no segundo processo. A lei espartana reduziu praticamente a zero o numero dos desgraçados por defeito fisico. Restavam os desgraçados por defeito mental [...]. Esses foram impedidos de se reproduzirem" (LOBATO, 1956c, p. 212).
}

Outras características ${ }^{61}$ desses Estados Unidos também são mencionadas: as mulheres haviam alcançado a igualdade cultural e social e os índios sido extintos. A história chega ao seu ponto principal quando as eleições para a presidência começam a ser descritas. Tradicionalmente, as mulheres tinham sua própria candidata, e os negros votavam com os homens brancos. Dessa vez, todavia, quando do anúncio do resultado da eleição, uma surpresa: o líder dos negros, Jim Roy, havia vencido (LOBATO, 1956c).

\footnotetext{
59 ESTADOS UNIDOS. Suprema Corte dos Estados Unidos. Buck v. Bell, 274 U.S. 200. 1927. Disponível em: <https://www.loc.gov/item/usrep274200/>. Acesso em: 5 mar. 2018.

60 Houve tentativas, por parte do governo estadunidense, especialmente durante os anos que cercam a Guerra Civil (1861-1865), de efetivar um programa de imigração em massa dos negros libertos para a região amazônica (HORNE, 2010). Nas primeiras décadas do século XX, como se pode verificar pelos jornais da época, havia a preocupação de que algo semelhante viesse a acontecer. Motivo central da rejeição era a alegada postura "inassimilável" dos negros americanos (A NOITE. A campanha infamante do "Brazilian American Colonisation Syndicate". A Noite, capa, p.1. 27 jul. 1921.).

61 São notáveis algumas aproximações entre esses escritos de Lobato e a obra Brave new world, de Aldous Huxley, traduzida como Admirável mundo novo e originalmente publicada em 1932. Vê-se, na obra do inglês, uma sociedade também distópica, na qual a ciência era vista como caminho inequívoco para o progresso. Premissas éticas e crenças religiosas são tidas, nesse ambiente, como símbolos do atraso.
} 
A vitória inesperada resultou em uma corrida das mulheres em direção aos homens brancos, visando unir-se para salvar a raça. Em um encontro entre os líderes negro e branco, retomadas memoriais do passado escravista e da luta por sua liberdade são trazidas à tona. 0 clima tenso é revelado nas palavras do condutor do Partido Masculino, que afirma que, para além das razões de Estado, existem também razões de raça, e estas não raciocinam; são frias e cruéis (LOBATO, 1956c). A longa conversa termina com um abraço, precedido pela impactante afirmação do líder branco: "Acima da América está o sangue" (LOBATO, 1956c, p. 272).

Os opositores passam então a desdobrar-se em esforços para impedir a ascensão do partido e do líder eleitos. Temem a divisão da América, coisa que consideram um crime. A solução encontrada pela associação das mentes de homens e mulheres brancos é uma só: oferecer o alisamento do cabelo negro e, com isso, secretamente retirar a fertilidade daqueles que adotarem tal tratamento.

A alternativa da esterilização para o caso dos Estados Unidos foi mencionada por Kehl62 em um artigo publicado no Boletim de Eugenia na edição de junho/julho de 1929, poucos anos após a publicação de $O$ choque das raças. Na ocasião, o farmacêutico citou o livro de Paulo Prado, Retrato do Brasil: "Na sua complexidade o problema estadunidense não tem solução, dizem os cientistas americanos, a não ser que se recorra à esterilização do negro".63 Prado é elogiado por Lobato em carta enviada a Kehl no mês de outubro do mesmo ano. Possivelmente o taubateano já tinha a referida edição do boletim em mãos : ${ }^{64}$ "O livro do Prado é terrível, é retrato fidelissimo. Prado portanto deve estar muito mal visto. Falar a verdade passou a ser crime entre nós. Voce vae-Ihe nas aguas. Diz tudo o que é preciso dizer. Cuidado! Elles acabam te linchando" (LOBATO, 1929b).

No mesmo livro citado, Prado escreve: "O que se chama a arianização do habitante do Brasil é um fato de observação diária [...]. E assim, no cruzamento contínuo da nossa vida [...] o negro desaparece aos poucos". ${ }^{65}$ Destaca-se que o autor, tomado em alta conta por Lobato e Kehl, assumia como verdadeiro o processo de branqueamento. Diferentemente, no entanto, do que se vê em outros defensores dessa tese, não fica claro se Prado considera tal desenvolvimento uma característica inteiramente positiva. O contraste entre a "solução" americana - leia-se segregação - e a "solução" brasileira - ou seja, "assimilação" - era artifício comum entre os intelectuais que assumiam a tese do branqueamento. ${ }^{66}$

As dúvidas que pudessem sondar o futuro racial do Brasil durante as primeiras décadas do século XX não se efetivavam nos Estados Unidos futurísticos. O ideal de "super-civilização ariana" estava desabrochando e, por meio do "manso ponto final étnico", a "esplendorosa

\footnotetext{
62 KEHL, Renato. Questões de Raça. Boletim de Eugenia, n.6-7. 1929b.

63 PRADO, Paulo. Retrato do Brasil. 2. ed. São Paulo: IBRASA. 1981, p. p. 138-139.

${ }^{64}$ As cartas analisadas indicam que Kehl enviava, com frequência, volumes do boletim para o escritor paulista.

65 PRADO, Paulo. Op. cit, p. 137.

66 SKIDMORE, Thomas E. Op. cit.
} 
florescencia do homem branco" poderia, enfim, acontecer (LOBATO, 1956c, p. 323). Quando recebe, surpreso, a informação sobre a inesperada consequência do tratamento estético, Jim Roy é tomado por profunda tristeza, amanhecendo morto em seu gabinete. Submetido ao ódio racial, o primeiro presidente negro não adentra na Casa Branca.

\section{Monteiro Lobato e Mr. Slang na América}

Em 1927, Mr. Slang, já mencionado neste texto, surgiu nas páginas de Lobato. Ainda na primeira aparição, em Mr. Slang e o Brasil, é possível observar que ele é uma espécie de alter ego do escritor, compartilhando com ele seu ceticismo, a admiração por Ruy Barbosa - que era entusiasta da higiene e da educação - , a crítica aos jornais brasileiros, a ode à eficiência de Henry Ford e a atração pelo pensamento nietzschiano (LOBATO, 1966). É no segundo texto, de 1932, intitulado América, no entanto, que vemos uma síntese dos pensamentos do autor e a reintrodução de temas abordados em "O presidente negro".

Em seu cerne, o livro desenha a importância da "eficiência" para a formação dos Estados Unidos. Nesse momento, já profundamente tocado pelas potencialidades da indústria, Lobato procurou estimular uma visão positiva a respeito do padrão de vida norte-americano. É interessante notar que tal postura se deu num momento de crise do capitalismo internacional, manifestada pela Grande Depressão, em 1929, que fez com que o escritor perdesse o dinheiro que havia investido na bolsa de valores de Nova York. ${ }^{67}$

Reapareceu em América uma constatação que em carta ao amigo Rangel datada de 1925 o autor já havia feito: "Não tenho o índio ou o negro na alma. O tropicalismo me parece coisa de índio e negro da Africa" (LOBATO, 1961b, p. 283). Seguindo raciocínio semelhante, Mr. Slang expõe, nas páginas do texto, sua teoria de que "apenas encontram encantos num país tropical o bugre e o negro d'Africa" (LOBATO, 1966, p. 94). É notável que Lobato tenha sido bastante assertivo ao confessar, mais de uma vez (LOBATO, 1964b, p. 200), que ele era um "peixe que esteve fora d'agua desde 1882 [...], e só agora caiu nela. Isso aqui é o mar do peixe Lobato" (LOBATO, 1961b, p. 302). Identificando-se com os Estados Unidos, ele acaba utilizando o país como referencial para seus olhares sobre o Brasil.

O tema da eugenia é materializado nesse texto, entre outras formas, por meio da crítica à ideia de caridade. O narrador e Mr. Slang afirmam que a solução científica para os "aleijados e cegos e órfãos" é o fim das atitudes piedosas, que são a razão pela qual indivíduos imperfeitos permanecem vivos. Apenas pela ação da "química e da eugenia" a inútil ideia da caridade pode ser superada (LOBATO, 1966, p. 37). A crítica à caridade é pauta comum no movimento eugenista, como se vê, por exemplo, em Renato Kehl, que considera uma infelicidade que, "via

\footnotetext{
67 CAVALHEIRO, Edgard. Op. cit.
} 
de regra, procura-se tudo favorecer aos medíocres, aos doentes, aos incapazes, que por isso conseguem vencer". 68

As observações do historiador inglês Henry Thomas Buckle (1821-1862) sobre o Brasil foram reverenciadas em seu contexto, pois legitimavam um determinismo de caráter geográfico: "Grande é o fluxo e a abundância de vida pela qual o Brasil é marcado, sobre todos os outros países da terra". ${ }^{69}$ Observa o autor, todavia, que: "Em meio a tanta pompa e esplendor da natureza, nenhum espaço sobrou para o Homem". ${ }^{70} \mathrm{Em}$ América, o tema é mencionado, e a superioridade da Europa e dos Estados Unidos, reafirmada, partindo da ideia de que, pelo fato de não haver épocas de frio intenso nas terras do sul, o brasileiro não se preocupava com excedentes produtivos, sempre cultivando o mínimo possível para sua sobrevivência (LOBATO, 1966).

A noção de purificação, estruturante no ideário racista, é acessada também nesse livro. Após contar o caso da mulher que se separou do marido por descobrir que em seu sangue corria sangue africano, o inglês responde à interpelação horrorizada do narrador, que lhe questiona se não julga tal atitude odiosa: "Não sei se não será isto um instinto da raça que se defende. Cruel, confesso. Crudelissimo, neste caso" (LOBATO, 1966, p. 203), e completa com um trecho que lembra o discurso do líder branco de "O presidente negro": "Mas os altos interesses da pureza da raça não estarão acima dos pequeninos interesses do individuo?" (LOBATO, 1966, p. 203). Essa era a perspectiva adotada por muitos eugenistas norte-americanos, ingleses e alemães. ${ }^{71}$ Seria essa a "filosofia horrível", mencionada no trecho suprimido de 1908 ?

É de se suspeitar que a ideia de que todos os negros americanos tivessem se tornado brancos, em termos físicos, pode ser referência à noção de branqueamento já aqui discutida. Assim, Lobato poderia estar insinuando que, por mais brancos que fossem os mulatos, eles nunca seriam puros como os arianos. Na história resumida no parágrafo anterior, detalhe importante é que mulher e marido estavam juntos já havia cinco anos, e esta não desconfiava que seu cônjuge tivesse qualquer elemento negro em seu sangue. Como Kehl, é plausível que o taubateano, ao assumir uma leitura mendeliana de hereditariedade, compreendesse que traços típicos de uma raça pudessem permanecer escondidos na constituição genética individual.

A "civilização americana" é superior na medida em que se aproxima da natureza, da "satisfação normal dos seus 'urges' orgânicos" (LOBATO, 1966, p. 208). Contribui para esse processo o desenvolvimento da ciência da higiene, que podemos entender aqui como a

\footnotetext{
${ }^{68} \mathrm{KEHL}$, Renato. Os erros da filantropia: filantropia contra-seletiva. Boletim de Eugenia, n.32, 1931, p.1.

${ }^{69}$ BUCKLE, Henry Thomas. History of civilization in england. Nova York: D. Appleton and Company. 1884. v. 1, p. 75. Buckle influenciou vários nomes da intelectualidade nacional, tais como Sílvio Romero, Euclides da Cunha e Capistrano de Abreu, como revela MURARI, Luciana. "Brasil, ficção geográfica": ciência e nacionalidade no país d'Os Sertões. Belo Horizonte: FAPEMIG. 2007, p. 66-67. Nota-se ainda que tal noção já está presente em "Urupês" (LOBATO, 2014b, p. 176) e foi apropriada de forma crítica em alguns dos artigos de "Problema vital" (LOBATO, 1956a).

70 BUCKLE, Henry Thomas, Idem.

71 KEVLES, Daniel J. In the name of eugenics: genetics and the uses of human heredity. Cambridge: Harvard University Press. 1995; BLACK, Edwin, Op. cit.
} 
propagação de medidas de cunho sanitarista. "Mas não basta a higiene. Temos de chegar á Eugenia"72 (LOBATO, 1966, p. 208), assevera Mr. Slang. O "homem de amanhã", perfeito, será construído por intermédio da ação da ciência. Para isso, é preciso superar os limites morais do cristianismo, pois o "avanço da Eugenia se faz em progressão diretamente proporcional ao retrocesso da religião" (LOBATO, 1966, p. 208).

Retomamos a carta de 1908 buscando agora conciliar o excerto suprimido com um trecho que ainda pode ser encontrado nas edições mais recentes de A barca de Gleyre. Antes de condenar a feiura da degenerescência gerada pela mestiçagem, Lobato acusa o cristianismo de ter fundado um "culto ao feio". Em América, Mr. Slang afirma que sempre se impressionou "com a feiura que trouxe para a humanidade a religião e as morais saidas da religião" (LOBATO, 1966, p. 208). O desprezo da matéria e do corpo, assentado nas doutrinas cristãs na Idade Média, é criticado na sequência. Posição de semelhante teor é tomada por Renato Kehl, em 1929,73 que considera aquele momento histórico como um período de "trevas e humilhação do corpo".

Apesar de ser uma apologia aos Estados Unidos, o texto de América também direciona algumas críticas aos norte-americanos, a começar pela censura, motivada pela cultura puritana. Ela seria a responsável por estabelecer limites ao cinema, que ainda não havia revelado sua máxima expressão (LOBATO, 1966, p. 138). Outro problema que Mr. Slang diagnosticava nos Estados Unidos era a crescente influência das mulheres, derivada diretamente das vitórias do feminismo (LOBATO, 1966, p. 185). Por fim, destaca os males do consumo desenfreado, um dos excessos da realidade capitalista (LOBATO, 1966, p. 261).

A discussão entre o inglês e o narrador desenvolve-se, a partir daí, para uma exposição a respeito da importância do petróleo e do ferro para a garantia do desenvolvimento do Brasil. Esses dois temas, aliás, ocupariam o resto da vida de Monteiro Lobato. A mudança de foco do autor, nesse momento, parece estar associada a uma busca por outros caminhos para a construção de um país e de uma nacionalidade. Apesar de ter se mantido na luta pelo progresso brasileiro, o autor voltou poucas vezes, desde então, aos preceitos eugenistas. Assim, seu projeto de Brasil parece ter se deslocado, mais definitivamente, do tipo humano para as condições políticas, culturais, educacionais e econômicas da nação (LOBATO, 1955).

\section{Considerações finais}

\footnotetext{
72 Tal afirmação é feita também por Renato Kehl, no trecho de seu discurso no Primeiro Congresso de Eugenia, que aqui mencionamos. É interessante notar que Lobato teve contato com esse texto, já que admite, em carta a Kehl, ter recebido a conferência realizada por ele no evento (LOBATO, 1929b).

$73 \mathrm{KEHL}$ apud CARVALHO, Leonardo Dallacqua. O resgate dos antigos para a propaganda da eugenia de Renato Kehl em Lições de Eugenia (1929). Geografia e Pesquisa, v.7, n.2, p. 58. Disponível em: <http://vampira.ourinhos.unesp.br/openjournalsystem/index.php/geografiaepesquisa/article/view/167>. Acesso em: 22 dez. 2019. 19 set. 2014.
} 
Uma investigação é sempre construída mediante uma seleção de fontes. A exposição em série de excertos que trazem menções a temas tão polêmicos quanto os aqui citados, não obstante, pode fazer parecer que há predominância desse tipo de discussão nos escritos de Monteiro Lobato. Estaríamos equivocados se assim afirmássemos. Mesmo nas cartas acessadas, trocadas entre o escritor e seus interlocutores na ciência, especialmente Renato Kehl e Artur Neiva, esse assunto não ocupa a maior parte das linhas. Quando não está falando dos negócios de sua editora, como acontece nas correspondências com o primeiro, Lobato procura persuasivamente ganhar a atenção do segundo para seu projeto das indústrias do petróleo e do ferro no Brasil.

O fato é que o autor construiu sua vida intelectual em um ambiente evolucionista. O extravasamento desse paradigma para as estruturas sociais tornou natural para alguns intelectuais que a ideia da igualdade entre os homens era tão absurda quanto a igualdade entre diferentes espécies de animais. Em uma anotação, provavelmente de 1932, Lobato escreveu: "Sendo o homem um perfeito animal, submetido às mesmas leis biológicas que o evolucionismo estabeleceu [...], seria supinamente ridículo que as aplicássemos a todos os sêres, com exceção apenas do homem" (LOBATO, 1964c, p. 187). No mesmo texto, ainda afirma: "Assim, um bechuana (negro do Sul da África) assemelha-se intelectual e moralmente, muito mais a um gorila do que, naturalmente, a um holandês ou italiano" (LOBATO, 1964c, p. 187).

A redenção do Jeca Tatu, depois da publicação de Problema vital, não foi mais questionada pelo autor. Em 1947, ele até mesmo reforçaria a transposição da culpa, atribuída em "Urupês" ao caboclo, para as estruturas sociais e políticas, com a publicação de Zé Brasil, livreto em que defende, entre outras coisas, a reforma agrária. Não há, contudo, redenção do indígena nem do negro. É possível dizer que a esperança de que a ciência fosse capaz de alterar o destino humano foi projetada com mais ênfase quando a população-alvo era fruto das relações entre europeus e indígenas: características paulistas, constituição ideal do bandeirante. ${ }^{74}$

Nota-se também que a discussão de "O presidente negro" não é sobre o Jeca, como foi parte considerável dos escritos de Lobato. Falar do caboclo não faria sentido se o objetivo fosse ganhar dinheiro no mercado de livros estadunidense. Em $O$ choque das raças, encontramos a luta entre brancos e negros, e não entre o caipira e seus parasitas. Mas o Jeca, escreve Lobato (2014b, p. 171), está entre o "aborígene de tabuinha no beiço" e o "estrangeiro recente". Disso emerge um questionamento referente ao papel do negro no projeto de Brasil delineado de maneira tão dinâmica no conjunto da obra do escritor paulista.

\footnotetext{
${ }^{74}$ Apoiamo-nos aqui na definição de caboclo utilizada por Antônio Candido (2010, p. 27), que observa que o termo caboclo no primeiro sentido, designa "o mestiço próximo ou remoto de branco e índio, que em São Paulo forma talvez a maioria da população tradicional". In. CANDIDO, Antonio. Os parceiros do Rio Bonito: Estudo sobre o caipira paulista e a transformação dos seus meios de vida. Rio de Janeiro: Ouro sobre azul. 2010, p.27.
} 
Parece-nos um equívoco afirmar, de maneira açodada, que o autor defendia a aplicação do método da raça branca à realidade brasileira. É questionável também se o único trecho em que há um reclame tão claro pela violência de raça é suficiente para que enquadremos o autor em um movimento terrorista como a Ku Klux Klan, ou mesmo argumentemos que ele urgia pela eliminação dos negros. Se poucas linhas fossem suficientes para comprovar algo, a depender dos recortes escolhidos nas obras de Lobato, poderíamos sustentar que ele era, ao mesmo tempo, comunista, liberal e monarquista, pois há farto material para cada uma dessas insinuações.

A dureza dessa temática não impede que afirmemos, no entanto, que o escritor conhecia o movimento eugenista e dominava alguns de seus preceitos centrais, expostos já em "O presidente negro". Também é perceptível que ele havia entrado em contato com o material que se produzia nos Estados Unidos, uma vez que desanimou Kehl, mesmo reconhecendo nele uma figura fundamental do eugenismo brasileiro, a tentar publicar sua obra nos Estados Unidos, porque "não pode haver paiz onde a eugenia esteja mais proclamada, estudada, praticada, 'livrada' do que este" (LOBATO, 1929a).

O alinhamento com Kehl e Neiva, bem como a menção elogiosa a Paulo Prado, permite esboçar uma hipótese sobre a questão racial em Lobato. Assim como o indígena é diluído na figura do caipira, que, por sua vez, é redimido pela ciência, as discussões aqui realizadas abrem espaço para que se vislumbre uma identidade nacional ligada, senão ao antigo projeto de branqueamento, pelo menos a uma noção de homogeneidade demográfica. Uma leitura, como a feita por Prado, ${ }^{75}$ de que o processo de miscigenação é inevitável, também possibilita entender porque o autor recorreu pouco à temática racial em seus escritos mais tardios: seu pragmatismo impedi-lo-ia de empreender esforços sobre questões já determinadas.

De uma ou de outra forma, Monteiro Lobato buscava soluções para o país. As influências que recebeu das teorias científicas que lhe foram contemporâneas moldaram parte de suas posturas nessa empreitada. É razoável reconhecer preceitos eugenistas e posicionamentos racistas nos escritos lobatianos. Não se pode esclarecer, todavia, a profundidade do comprometimento prático do autor com a manipulação da reprodução humana em prol de um projeto biológico normativo de homem nacional. Em primeiro lugar, porque o véu da ficção ofusca, nos textos mais explícitos, posições objetivas. Em segundo lugar, porque a vida militante do escritor, comprometida com a construção de um país e de uma população trabalhadora, saudável e consciente, se pautou na luta contra a pobreza por meio da modernização produtiva. Nessa batalha, seus principais inimigos eram brancos, biologicamente adequados e poderosos.

75 PRADO, Paulo. Retrato do Brasil... Op. cit. 


\section{Referências}

A NOITE. A campanha infamante do "Brazilian American Colonisation Syndicate". A Noite, capa, p.1. 27 jul. 1921.

ANTONIOS, Nathalie; RAUP, Christina. Buck v. Bell (1927). Disponível em: <https://embryo.asu.edu/pages/buck-v-bell-1927>. Acesso em: 4 abr. 2019. 2012.

BLACK, Edwin. A guerra contra os fracos: a eugenia e a campanha dos Estados Unidos para criar uma raça dominante. São Paulo: A Girafa. 2003.

BUCKLE, Henry Thomas. History of civilization in england. Nova York: D. Appleton and Company. 1884. v. 1.

CAMPOS, André Luiz Vieira de. A República do Picapau Amarelo: uma leitura de Monteiro Lobato. São Paulo: Martins Fontes. 1986.

CANDIDO, Antonio. Os parceiros do Rio Bonito: Estudo sobre o caipira paulista e a transformação dos seus meios de vida. Rio de Janeiro: Ouro sobre azul. 2010.

CARVALHO, Leonardo Dallacqua. O resgate dos antigos para a propaganda da eugenia de Renato Kehl em Lições de Eugenia (1929). Geografia e Pesquisa, v.7, n.2. Disponível em: <http://vampira.ourinhos.unesp.br/openjournalsystem/index.php/geografiaepesquisa/article/v iew/167>. Acesso em: 22 dez. 2019. 19 set. 2014.

CAVALHEIRO, Edgard. Monteiro Lobato: vida e obra. 3. ed. São Paulo: Brasiliense. 1962. 2 v. DE SOUZA, Leonardo Cruz et al. A poética de Augusto dos Anjos e a neuropsiquiatria no fin de siècle. História, Ciências, Saúde-Manguinhos, v.25, n.1, p.163-179. 2018.

DIWAN, Pietra. Raça Pura. São Paulo: Contexto. 2007.

ENDALÉCIO, Raquel Nunes. A (re)construção do mundo clássico na obra de Monteiro Lobato: fontes e procedimentos. Dissertação (Mestrado em Estudos Brasileiros) - Universidade de São Paulo, São Paulo. 2013. Disponível em: <https://bv.fapesp.br/pt/dissertacoes-teses/82668/are-construcao-do-mundo-classico-na-obra-de-monteiro-lobato>. Acesso em: 13 dez. 2019.

ESTADOS UNIDOS. Suprema Corte dos Estados Unidos. Buck v. Bell, 274 U.S. 200. 1927. Disponível em: <https://www.loc.gov/item/usrep274200/>. Acesso em: 5 mar. 2018.

GALTON, Francis. Inquiries into human faculty and its development. Nova York: MacMillan and Co. 1883.

GALTON, Francis. Hereditary Genius: an inquiry into its laws and consequences. 2. ed. Londres: Macmillan and Co. 1892.

HABIB, Paula Arantes Botelho Briglia. Eis o mundo encantado que Monteiro Lobato criou: raça, eugenia e nação. 2003. 175 p. Dissertação (mestrado) - Universidade Estadual de Campinas, Instituto de Filosofia e Ciencias Humanas, Campinas, SP. Disponível em: <http://www.repositorio.unicamp.br/handle/REPOSIP/281539>. Acesso em: 3 ago. 2018. 
HOCHMAN, Gilberto; LIMA, Nísia Trindade. "Pouca saúde e muita saúva": sanitarismo, interpretações do país e ciências sociais. In: Armus, Diego; Hochman, Gilberto (Orgs.). Cuidar, controlar, curar: ensaios históricos sobre saúde e doença na América Latina e Caribe. Rio de Janeiro: FIOCRUZ. p.493-534. 2004.

HORNE, Gerald. O Sul mais distante: os Estados Unidos, o Brasil e o tráfico de escravos africanos. São Paulo: Companhia das Letras. 2010.

KEHL, Renato. A eugenia no Brasil. In: Couto, M. (Org.). Primeiro Congresso Brasileiro de Eugenia: Actas e Trabalhos. Rio de Janeiro. p.45-62. 1929c.

KEHL, Renato. O nosso boletim. Boletim de Eugenia, v.1, n.1. 1929a.

KEHL, Renato. Questões de Raça. Boletim de Eugenia, n.6-7. 1929b.

KEHL, Renato. Os erros da filantropia: filantropia contra-seletiva. Boletim de Eugenia, n.32, p.1. 1931.

KEVLES, Daniel J. In the name of eugenics: genetics and the uses of human heredity. Cambridge: Harvard University Press. 1995.

LIGA BRASILEIRA DE HYGIENE MENTAL. Estatutos da Liga Brasileira de Hygiene Mental. Archivos Brasileiros de Hygiene Mental, v.1, n.1, p.223-234. 1925.

LIMA, Nísia Trindade; HOCHMAN, Gilberto. Condenado pela raça, absolvido pela medicina: o Brasil descoberto pelo movimento sanitarista da Primeira República. In: Maio, Marcos Chor; Santos, Ricardo Ventura (Orgs.). Raça, ciência e sociedade. Rio de Janeiro: FIOCRUZ. p.23-40. 1996.

LOBATO, Monteiro. Correspondência a Renato Kehl. Fundo Pessoal Renato Kehl - DAD-COC. 6 abr. 1918.

LOBATO, Monteiro. Correspondência a Artur Neiva. Arquivo Artur Neiva - CPDOC-FGV. [1926].

LOBATO, Monteiro. Correspondência a Renato Kehl. Fundo Pessoal Renato Kehl - DAD-COC. [1926 ou 1927].

LOBATO, Monteiro. Correspondência a Artur Neiva. Arquivo Artur Neiva - CPDOC-FGV. 10 abr. 1928.

LOBATO, Monteiro. Correspondência a Renato Kehl. Fundo Pessoal Renato Kehl - DAD-COC. 8 jul. 1929a.

LOBATO, Monteiro. Correspondência a Renato Kehl. Fundo Pessoal Renato Kehl - DAD-COC. 9 out. $1929 \mathrm{~b}$.

LOBATO, Monteiro. O escândalo do petróleo e do ferro. 7. ed. São Paulo: Brasiliense. 1955.

LOBATO, Monteiro. Mr. Slang e o Brasil. In: Lobato, Monteiro. Mr. Slang e o Brasil e problema vital. 7. ed. São Paulo: Brasiliense. p.5-126. 1956a.

LOBATO, Monteiro. O presidente negro. In: Lobato, Monteiro. A onda verde e o presidente negro. 7. ed. São Paulo: Brasiliense. p. 125-324. 1956b.

LOBATO, Monteiro. Problema vital. In: Lobato, Monteiro. Mr. Slang e o Brasil e problema vital. 7. ed. São Paulo: Brasiliense. p.223-329. 1956c.

LOBATO, Monteiro. A Barca de Gleyre. 10. ed. São Paulo: Brasiliense. 1961a. v. 1. 
LOBATO, Monteiro. A Barca de Gleyre. 10. ed. São Paulo: Brasiliense. 1961b. v. 2.

LOBATO, Monteiro. Literatura do Minarete. 2. ed. São Paulo: Brasiliense. 1961c.

LOBATO, Monteiro. Cartas escolhidas. 3. ed. São Paulo: Brasiliense. 1964a. v. 1.

LOBATO, Monteiro. Cartas escolhidas. 3. ed. São Paulo: Brasiliense. 1964b. v. 2.

LOBATO, Monteiro. Conferências, artigos e crônicas. 3. ed. São Paulo: Brasiliense. 1964c.

LOBATO, Monteiro. America. 13. ed. São Paulo: Brasiliense. 1966.

LOBATO, Monteiro. Negrinha. In: Lobato, Monteiro. Contos completos. São Paulo: Biblioteca Azul. p.339-518. 2014a.

LOBATO, Monteiro. Urupês. In: Lobato, Monteiro. Contos Completos. São Paulo: Biblioteca Azul. p.37-191. 2014b.

MENDES, Priscilla. Mais uma obra de Monteiro Lobato é questionada por suposto racismo. G1, Brasília, 25 set. 2012. Educação. Disponível em: < http://g1.globo.com/educacao/noticia/2012/09/mais-uma-obra-de-monteiro-lobato-equestionada-por-suposto-racismo.html>. Acesso em: 11 jan. 2021.

MURARI, Luciana. "Brasil, ficção geográfica": ciência e nacionalidade no país d'Os Sertões. Belo Horizonte: FAPEMIG. 2007.

NOGUEIRA, Eloisa Alves. O eu e o outro: o legado de dois pais contado por Machado de Assis e Godofredo Rangel. Dissertação (Mestrado em Literatura Brasileira) - Universidade Federal de Juiz de Fora, Juiz de Fora, 2017. Disponível em: <https://repositorio.ufjf.br/jspui/handle/ufjf/6564>. Acesso em: 4 ago. 2019.

PENNA, Belisário. Saneamento dos sertões I. Correio da Manhã, p.2. 1916.

PRADO, Paulo. Retrato do Brasil. 2. ed. São Paulo: IBRASA. 1981.

ROQUETTE-PINTO, Edgard. Notas sobre os typos anthropologicos do Brasil. In: Couto, M. (org.). Primeiro Congresso Brasileiro de Eugenia: Actas e Trabalhos. Rio de Janeiro. p.119-148. 1929.

SANTOS, Alessandra Rosa. Quando a Eugenia se distancia do Saneamento: as ideias de Renato Kehl e Octávio Domingues no Boletim de Eugenia (1929-1933). 2005. Dissertação (Mestrado em História das Ciências e da Saúde) - Casa de Oswaldo Cruz, Fundação Oswaldo Cruz, Rio de Janeiro, 2005.

SANTOS, Ricardo Augusto dos. O manifesto eugenista. In: Penna, Antonio Gomes (Org.). Manifestos Políticos do Brasil Contemporâneo. Rio de Janeiro: E-Papers. p.53-63. 2008.

SCHWARCZ, Lilia Moritz. O espetáculo das raças: cientistas, instituições e questão racial no Brasil; 1870-1930. São Paulo: Schwarcz. 2004.

SEVCENKO, Nicolau. Literatura como missão: tensões sociais e criação cultural na primeira República. 4. ed. São Paulo: Brasiliense. 1995.

SILVA, Míriam Porfírio da. O americanismo de Monteiro Lobato: análise dos livros "Mister Slang e o Brasil" e "América". Dissertação (mestrado) - Universidade Estadual de Campinas, Faculdade de Educação, Campinas, 2018.

SKIDMORE, Thomas E. Black into white: race and nationality in Brazilian thought. Durham: Duke University Press Books. 1992. 
SOUZA, José Wellington de. Raça e Eugenia na Obra Geral de Monteiro Lobato. Tese (Doutorado em Ciências Sociais) - Universidade Federal de Juiz de Fora, Juiz de Fora, 2017.

SOUZA, Rômulo Pinto de. Tradução, ordenação e reescrita: um Hans Staden à brasileira ou Lobato, um leitor do Brasil?. Dissertação (Mestrado em Letras) - Universidade Federal Fluminense, Niterói, 2013.

SOUZA, Vanderlei Sebastião de. A política biológica como projeto: a eugenia negativa e a construção da nacionalidade na trajetória de Renato Kehl (1917-1932). Dissertação (Mestrado em História das Ciências e da Saúde) - Casa de Oswaldo Cruz, Fundação Oswaldo Cruz, Rio de Janeiro, 2006. Disponível em: <https://www.arca.fiocruz.br/handle/icict/6134>. Acesso em: 12 maio. 2018.

SOUZA, Vanderlei Sebastião de. As idéias eugênicas no Brasil: ciência, raça e projeto nacional no entre-guerras. História em Reflexão, v.6, p.1-23. 2012.

SOUZA, Vanderlei Sebastião de. A eugenia brasileira e suas conexões internacionais: uma análise a partir das controvérsias entre Renato Kehl e Edgard Roquette-Pinto, 1920-1930. História, Ciências, Saúde-Manguinhos, v.23, n.1, p.93-110. 2016.

SOUZA, Vanderlei Sebastião de. Em busca do Brasil: Edgard Roquette-Pinto e o retrato antropológico brasileiro (1905-1935). Tese (Doutorado em História das Ciências e da Saúde) Casa de Oswaldo Cruz / Fiocruz, Rio de Janeiro, 2011. 382 f.

STEPAN, Nancy Leys. "A hora da Eugenia": raça, gênero e nação na América Latina. Rio de Janeiro: Editora Fiocruz, 2005.

STEPAN, Nancy Leys. Eugenia no Brasil, 1917-1940. In: HOCHMAN, Gilberto; ARMUS, Diego (Orgs.). Cuidar, controlar, curar: ensaios históricos sobre saúde e doença na América Latina e Caribe. Rio de Janeiro: FIOCRUZ. p.331-391. 2004.

TAMANO, Luana Tieko Omena et al. O cientificismo das teorias raciais em $\mathrm{O}$ cortiço e Canaã. História, Ciências, Saúde-Manguinhos, v.18, n.3, p.757-774. 2011.

TIN, Emerson. Em busca do "Lobato das cartas": a construção da imagem de Monteiro Lobato diante de seus destinatarios. 2007. Tese (doutorado) - Universidade Estadual de Campinas, Instituto de Estudos da Linguagem, Campinas, SP, 2007.

TODOROV, Tzvetan. Imperfect garden: the legacy of humanism. Princeton: Princeton University Press. 2002.

TURDA, Marius. Modernism and eugenics. Nova York: Palgrave MacMillan. 2010. 